\title{
Функции настоящего и имперфекта совершенного виАа и перфекта несовершенного вида в момизско- славянском микроязыке
}

\author{
Вальтер Брой \\ Universität Konstanz, FB Sprachwissenschaft Slavistik, \\ Konstanz D-78457 Germany.walter.breu@uni-konstanz.de
}

\begin{abstract}
Walter Breu: The Functions of the Perfective Present/Imperfect and the Imperfective Perfect in the Molise Slavic Micro-Language

This paper deals with the functions of Molise-Slavic verb forms expressing "contradictory" combinations of aspect grammemes: the perfective present, the perfective imperfect, and the imperfective perfect. Molise Slavic is a South Slavic minority language based historically on the Serbo-Croatian dialect continuum, which since the arrival of the ancestors of today's native speakers has been influenced to a large extent by the Romance varieties of the Southern Italian Region of Molise. In spite of its "total language contact" situation with all its speakers being bilingual, Molise Slavic has retained, in principal, its original Slavic aspect oppositions, both the inflectional one (imperfect : perfect) and the derivational one (imperfective : perfective), freely combining with each other. Nevertheless, a reorganization of the inflectional category has occurred, following the regional Romance model (in losing the aorist but not the imperfect), and nowadays there is a certain dominance of the inflectional opposition over the derivational one. The non-contradictory combinations of the imperfect (and the present) with the imperfective aspect, as well as the combination of the perfect with the perfective aspect, continue to express aspectual oppositions in non-iterative situations. In the following we will show that the contradictory combinations have not been lost either. In spite of the pressure coming from the unmarked, non-contradictory forms, they still have functions of their own, especially in the field of aspectual oppositions in iterative, habitual, or distributive situations, but also in some other fields.
\end{abstract}

Keywords: Minority languages, language contact, verbal aspect, imperfect, imperfective, perfect, perfective, Molise Slavic, iteration, irrealis, counterfactual. 


\section{0. Введение}

Молизско-славянский язык (сокращённо МСЯ), является среАством общения славянского меньшинства в южно-итальянском регионе Молизе. ${ }^{1}$ Этот славянский языковой остров заселики мюди из внутренней части Аалмации (Герцеговины). Общие корни МСЯ с современным штокавско-икавским наречием сербохорватского Аиалектного континуума еще хорошо различимы и на данный момент. Его диалектная основа с точки зрения сербохорватистики, а также его отличия от стандартов БСХ (боснийско-сербско-хорватского) преАставлены в пункте (1):

(1) a. МСЯ: što 'что’ $\neq$ ča, kaj

б. МСЯ: mblika 'moloko' <*mlěko) $\neq$ mlijeko (хорв. стандарт), mleko (серб. стандарт)

в. МСЯ: превращение согласного -l в конце слова в -a как в Аолине реки Неретва:

sa hodija 'я ходик' $\neq$ стандарты БСХ: hodio sam (<*hodil) sa doša 'я пришен' $\neq$ стандарты БСX: došao sam (<*došal)

ПреАКи сегодняшних молизских славян прибыли в Италию, по всей вероятности, в начаме 16-ого столетия, и с тех пор оставались без существенного контакта со славянскими языками и диалектами балканского полуострова. Это значит, с оАной стороны, что МСЯ не участвовац в языковом развитии Аругих штокавских вариантов БСХ, например, в развитии окончания $-\bar{a}$ родительного падежа множественного числа. С этой точки зрения МСЯ является «архаичным». К его архаичным чертам принаАлежит, в принципе, также и сохранение синтетических форм прошеАшего времени глагола.

Но с Аругой стороны, из-за полутысячелетнего контакта с романскими языковыми системами, в мексике и грамматических структурах МСЯ укоренились кроме славянских и доминантные романские черты. Более того, Аля используемого в основном только в устной речи МСЯ итальянский является на сегодняшний день единственным доминантным (главенствующим) стандартным языком. Генетически наиболее близкий хорватский митературный язык не играет в повседневной жизни славянских

1 В этом введении повторяются некоторые общие факты о ситуации молизско-славянского (микро)языка. Более подробную информацию см., например, Breu 1997. 
молизан никакой роли, не говоря уже о том, что носители оАного языка почти не понимают носителей Аругого, и наоборот.

Территория распространения МСЯ охватывает три деревни, указанные в пункте (2), расположенные в южно-итальянском регионе Молизе, провинция Campobasso, приблизительно в 30-ти км от побережья ААриатического моря. В Аальнейшем мы будем употреблять Аанные зАесь сокращения:

(2) АК: Аквавива Комлекроче (Acquaviva Collecroce, мсл. Kruč), MM: Монтемитро (Montemitro, мск. Mundimitar) СФ: Сан Феличе (San Felice del Molise, мсл. Filič).

МСЯ находится сегодня в ситуации абсолютного языкового контакта. Это значит, что все говорящие владеют, по крайней мере, одним из вариантов итальянского языка. В двух деревнях, Аквавива Коммекроче и Монтемитро, МСЯ остается Ао сегоАняшнего Аня живым языком общения большинства населения (приблизительно 1000 человек), в то время как в третьей Аеревне, Сан Феличе, он почти полностью исчез из повсеАневного употребления. Внутридиалектные размичия довольно значительны. Например, наблюАается развитие «аканья», с произношением первоначальных кратких безударных - $о$ и -е в конце слова как -a, ограниченное говорами АК и СФ, и существуют три размичные формы Аательного падежа женского рода, не говоря уже о таких словарных размичиях, как njiva, largo, pajiz в смысле 'поле, нива'; ср. таблицу 1:

Таблица 1. Размичия межАу тремя говорами МСЯ (фонология, морфология, мексика)

\begin{tabular}{|c|c|c|c|}
\hline & Аканье & $\begin{array}{c}\text { Аательный падеж } \\
\text { еА. числа, ж. рода (класс *a) }\end{array}$ & поле, нива \\
\hline AK & + & -u (divojku ‘'евушке') & njiva \\
\hline MM & - & -Ø (divojk ‘Аевушке’) & largo \\
\hline СФ & + & -i (divojki ‘Аевушке’) & pajiz \\
\hline
\end{tabular}

ОАнако что касается виАа, все три говора МСЯ почти гомогенны. Важнее всего тот факт, что они все сохранили как фмективную, так и деривационную оппозицию виАа. Все процитированные ниже языковые примеры 
относятся, если не отмечено Аругое, к говору главной местности, Аквавивы.

\section{1. Состав форм молизско-славянского глагольного виАа}

\section{1. Фмективная видовая оппозиция}

СреАи славянских языков, которые находятся поА интенсивным вАиянием неславянских языков, МСЯ преАставляет собой тот специфический случай, когАа контактные языки, в Аанном скучае романские, также имеют категорию глагольного виАа (или аспекта) в форме «фмективной», точнее синтетически-аналитической видовой оппозиции в прошедшем времени. ${ }^{2}$

В общероманских рамках видовая фмективная оппозиция включает в себя три граммемы, указанные в пункте (3): имперфект, аорист (поитальянски passato remoto) и перфект (passato prossimo), которые нам хорошо известны также из славянских языков, например, из болгарского и македонского, а также из истории, например, русского языка.

Но в противоположность болгарскому и македонскому, МСЯ утратил аорист и заме-ниц его перфектом. В МСЯ, таким образом, сохранилась только Авучленная оппозиция «имперфект - перфект», как показано в пункте (4):

(3) первоначальная система слав./ром.

(4) МСЯ: имперфект аорист перфект

(5) слав. константа редукции: имперфект

(6) ром. константа реАукции: $\begin{array}{ccc}- & \text { аорист } & \text { перфект } \\ \text { имперфект } & - & \text { перфект }\end{array}$

На первый взгляА это положение Аел похоже на ситуацию в тех говорах сербохорватского языкового континуума, в которых синтетические формы глагольного вида, в принципе, еще продолжают существовать. Есть, оАнако, одно очень заметное разАичие, а именно, в противоположность молизско-славянскому языку, в этих говорах сохранился аорист, в то время как имперфект исчез и передал свои функции перфекту; ср. (5). Ааже

2 О системе глагольного вида МСЯ, включая также видовую интеграцию заимствованных глаголов, ср. Брой 2006. В этой статье также имеется более поАробное описание реАукции фмективной видовой оппозиции в МСЯ и в Аругих славянских языках, в особенности в БСХ (Брой 2006, 71-74). 
в тех вариантах сербохорватского языка, в которых еще используются обе синтетические видовые граммемы, имперфект употребляется реже аориста и не образует совершенного виАа. ${ }^{3}$

Исчезновение имперфекта при одновременном сохранении аориста в пункте (5) - явление, присущее не только сербохорватским диалектам. Оно наблюдается, например, также в истории русского языка и явцяется как раз одной из Аиахронических констант славянских языков.

С Аругой стороны, обзор романских языков, в том числе итальянского с его Аиалектами, показывает, что исчезновение аориста до имперфекта, отображенное в (6), явмяется диахронической константой романских языков. Что касается итальянского, то консервативный итальянский митературный язык, так же, как и консервативный БКС, сохраняет как имперфект, так и аорист, в то время как разговорная речь довольно большой части Италии, в том числе и в области молизскославянских деревень, больше не знает аориста. Утрата аориста наблюдается, кроме того, в местных молизских говорах итальянского языка. Таким образом, обе главные итальянские контактные разновидности МСЯ имеют редуцированную видовременную структуру, которая полностью совпадает со структурой сегоАняшнего МСЯ в (4). ${ }^{4}$

Из этого ясно, что МСЯ, хотя и слеАует общеславянской тенденции редукции фмективной категории вида, в соревновании Аиахронических констант выбрал путь романских языков. Аругими словами, славянская генетическая константа быма замещена романской генетической константой. Ареальное вмияние языкового контакта одержало победу наА генетическим РоАством.

3 В связи с утратой имперфекта до утраты аориста важно упомянуть общее наблюдение Ивича наА распространением аориста и имперфекта в сербохорватских говорах (см. Ivić 1958, 120): "Das Imperfekt wurde in einem beträchtlichen Teil des štok. Territoriums (Norden und Westen), der Aorist nur in einigen Randmundarten ganz ausgelöscht, während in manchen anderen Mundarten sein Gebrauch reduziert wurde." Также в митературных языках имперфект используется реже аориста. См., например, Raguž (1997, 185) о хорватском аористе: "Aorist... nije tako čest, ali je češći nego što se to tvrdi u hrvatskim gramatikama... Osobito je čest u književnim i povijesnim tekstovima", и в противоположность этому об имперфекте: "Praktično je imperfekt u suvremenome jeziku iščezlo glagolsko vrijeme".

4 Изоглосса межАу потерей аориста вблизи побережья и его сохранением внутри страны проходит по горной цепи позаАи Аквавивы. Все итальянские говоры, встречающиеся по направлению к морю, не обладают аористом. Говоры славянских деревень полностью вхоАят в этом отношении в итальянский диалектальный континуум. 
Имперфект молизско-славянского микроязыка преАставлен в таблице 2 на примере глагольной пары vamivat/vazet 'брать/взять', а именно формами говора деревни Аквавива. Окончания $\mathrm{HCB}$ и СВ, конечно, одинаковы. Согласно фонологическим правилам этого говора, формы имперфекта имеют аканье в окончаниях второго и третьего мица еА. числа имперфекта, т.е. vamivaša, вместо окончания -aše в говоре села Монтемитро, и в первом и во втором кице мн. числа, vamivahma, vamivahta, вместо -ahmo, -ahte. По аналогии к третьему мицу мн. числа, первое кицо еА. числа также получает окончание -ahu: vamivahu, vamahu (вместо первоначального окончнаия -ah).

Таблица 2: Имперфект глаголов vamivat/vazet Н/СВ ‘брать/взять’ в МСЯ (AK)

\begin{tabular}{|c|c|c|c|c|}
\hline & \multicolumn{2}{|c|}{ единственное число } & \multicolumn{2}{|c|}{ множественное число } \\
\hline имперфект & $\mathrm{HCB}$ & $\mathrm{CB}$ & $\mathrm{HCB}$ & $\mathrm{CB}$ \\
\hline 1-ое мицо & vamivahu & vamahu & vamivahma & vamahma \\
\hline 2-ое мицо & vamivaša & vamaša & vamivahta & vamahta \\
\hline 3-ье мицо & vamivaša & vamaša & vamivahu & vamahu \\
\hline
\end{tabular}

В таблице 3 преАставлены формы перфекта, которые образуются из форм вспомогательного глагола bit и причастия на -l. В качестве примера здесь приведено третье лицо с формами је и $s u$ вспомогательного глагола. Как обычно в славянских языках, формы перфекта различаются по роду и чисцу. Также, как в русском, но в противоположность хорватскому языку, формы множественного числа одинаковы дмя всех родов. Вследствие аканья формы женского и среднего рода еА. числа совпадают в говорах сел Аквавива и Сан Феличе, в то время как в говоре Монтемитро средний роА имеет собственное окончание -lo, напр. je vazelo 'оно взяло'. Формы мужского рода еА. числа на -a, је vaza 'он взял', је vamiva 'он брац', потеряли -l в конце слова во всех трех говорах молизско-славянского микроязыка, в то время как потеря гласного - $i$ в конце форм мн. числа объясняется правилами говоров Аквавивы и Монтемитро (в Сан Фекиче сохраняется окончание -li). 
Таблица 3: Перфект 3-го мица глаголов vamivat/vazet Н/СВ в МСЯ (АК)

\begin{tabular}{l|l|l|l|l} 
& \multicolumn{2}{|c|}{ еАинственное число } & \multicolumn{2}{c}{ множественное число } \\
\hline перфект & НСB & СВ & НCB & СВ \\
\hline мужской роА & je vamiva & je vaza & su vamival & su vazal \\
\hline женский роА & je vamivala & je vazala & su vamival & su vazal \\
\hline среАний роА & je vamivala & je vazala & su vamival & su vazal
\end{tabular}

Существуют и Аругие мексические варианты этой глагольной пары, напр. инфинитивы vamit, vast $\mathrm{CB}$ и vazimat $\mathrm{HCB}$, но формы, указанные в таблицах 2 и 3 - главные в Аиалекте села Аквавива.

\section{2. Формальное выражение деривационной видовой оппозиции}

Что касается Аеривационной видовой оппозиции СВ и НСВ, в МСЯ сохранились все обычные формальные способы образования видовых пар (= полных видовых глагольных мексем): префиксация, суффиксация и супплетивизм. Примеры преАставмены в таблице 4:

Таблица 4. Способы формирования гмагольных пар в МСЯ (АК)

\begin{tabular}{l|l|l} 
& \multicolumn{1}{|c|}{ НСВ } & \multicolumn{1}{|c}{ СВ } \\
\hline префиксация & $\begin{array}{l}\text { krest 'красть' } \\
\text { jist 'есть' } \\
\text { brat 'собирать' }\end{array}$ & $\begin{array}{l}\text { ukrest 'украсть' } \\
\text { jizist 'съесть' } \\
\text { nabrat 'собрать' }\end{array}$ \\
\hline суффиксация & $\begin{array}{l}\text { kupivat kupovat 'покупать' } \\
\text { umirat 'умирать' } \\
\text { stoknjivat 'резать' }\end{array}$ & $\begin{array}{l}\text { kupit 'купить' } \\
\text { umbrit 'умереть' } \\
\text { stoknit 'разрезать' }\end{array}$ \\
\hline супплетивизм & $\begin{array}{l}\text { mečat 'класть, ставить' } \\
\text { govorat 'говорить' } \\
\text { hot 'идти, ходить' }\end{array}$ & $\begin{array}{l}\text { vrс̌ 'положить, поставить } \\
\text { reč 'сказать' } \\
\text { рокj 'пойти' }\end{array}$
\end{tabular}

\section{2. ОАнородные (непротиворечивые) комбинации видов}

Как несовершенный виА, так и имперфект выражают нецемостные глагольные Аействия. С Аругой стороны, совершенный виА и перфект выражают целостные Аействия. Поэтому непротиворечивые комбинации 
«имперфекта НСВ», с одной стороны, «и перфекта СВ», с Аругой, можно считать «однородными комбинациями видовых форм». Функции этих комбинаций соответствуют в русском языке главным функциям прошеАшего несовершенного и совершенного виАов.

\section{1. Имперфект несовершенного виАа}

Например, имперфект несовершенного вида выражает мокализованный процесс, как в (7a), а также неограниченное состояние и неограниченное повторение действий, как в (76). С точки зрения таксиса ${ }^{5}$ имперфекты несовершенного НСВ выражают, например, полную оАновременность Авух процессов, как в (7в): ${ }^{6}$

(7) a. Do ne ure još rabaša imperf.ipf $_{\text {jud ka čistaša }}{ }_{\text {imperf.ipf }}$ grad. 'В этот час там еще работая мужчина, который чистия Аеревню.'

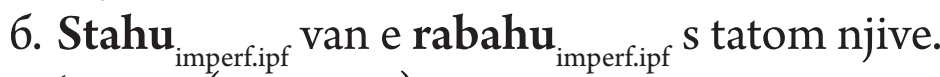
'Я жим (в Аомике) на поме и вместе с отцом обрабатывал поля.'

в. E kaka rabahu imperf.ipf $_{\text {kjikjarijahu }}$ imperf.ipf . 'И в то время как они работами, они беседовами.'

В этих функциях имперфект НСВ невозможно заменить перфектом НСВ. Иными словами, в отличие от русского или сербохорватского, ни в оАном из Аанных примеров не было бы возможно прошедшее на $-l$ НСВ.

\section{2. Перфект совершенного вида}

Вследствие совпадения аориста с перфектом, перфект СВ выражает, как и в русском, локализованные целостные действия (т.е. аористическую функцию), напр., в цепях действий, как показано в таксисной ситуации

5 Об употребляемой здесь терминологии в области таксиса ср. Храковский (2009). О роли виАа в таксисных конструкциях МСЯ ср., например, Брой (в печати).

6 Молизско-славянские языковые примеры взяты из молизско-славянской митературы, из корпуса устных текстов трех молизско-славянских Аиалектов в Breu/Piccoli и из банка Аанных славянских микроязыков EuroSlav 2010 (Adamou и Ар. 2013). При необходимости, примеры Ааны в сокращенной ими слегка измененной форме. EuroSlav 2010 состоит из глоссированного корпуса оригинальных устных текстов, опубликованного в интернете на сайте LACITO (Париж): http://lacito.vjf.cnrs.fr/archivage/ index.htm\#europe. Тексты можно также посиушать. 
предшествования в (8a). Перфект СВ может выражать также результат Аействий (выполняя собственно перфектную функцию), как в (8б):

(8) a. Činaša vruča, a kada je riva $a_{\text {perf.pf }}$ balunič, je sa ferma perf.pf $_{\text {za gledat }}$ vodu kaka skuraša.

'Бымо тепло, и когАа он доехал Ао ручья, он остановияся, чтобы посмотреть на воАу, как она течет.'

б. Ja sa sa naučila ${ }_{\text {perf.pf }}$ tuna.

'Я научимась всему.'

Кроме того также и таксисная функция неполной одновременности, так называемая «инциденция», как в примере (9), выражается исключительно однородными комбинациями имперфекта НСВ и перфекта СВ, если речь иАет о локализованных Аействиях:

(9) Kaka jidahu $\mathbf{i m p e r f . j p f}_{\text {, je osta }}$ perf.pf $s$ forčinom vaka mbača ruke (e je zaspa).

'В то время как они ели, он остановился с вилкой в руке (и уснук).

\section{3. Неоднородные комбинации}

Перейдем к функциям «противоречивых», т.е. неоднородных видовых комбинаций перфекта НСВ и имперфекта СВ. ${ }^{7}$

\section{1. Перфект несовершенного вида}

Общим яАром всех употреблений перфекта НСВ явмяется ограничение, т.е. мимитация непредемьных Аействий, как основных, так и второстепенных.

Что касается основных непредельных деятельностей и состояний, то конкретный тип их Аимитации зависит от типа глагольного Аействия. Существуют Ава класса состояний, которые можно ограничить: «реля-

7 О вопросе маркированности в области комбинаций видовых граммем МСЯ, в том числе о маркированном характере противоречивых комбинаций, ср. Брой 2006, 77-81. О теоретических вопросах взаимодействия видовых граммем разного типа, в том числе в болгарском, сp. Breu 1994, 35-39. 
тивно-статические» и «инцептивно-статические». ${ }^{8}$ А я употребления перфекта НСВ наиболее характерны инцептивно-статические мексемы, которые в русском языке обычно выражаются парными глаголами. В этих мексемах действие глагола НСВ следует за действием глагола СВ, а не наоборот, как у предельных, точнее «градуально-терминативных», глагомов типа кончать/кончить, строить/nостроить. Русскими примерами инцептивно-статических мексем явмяются, напр., понимать/понять, видеть/увидеть, и в принципе также знать/узнать.

Инцептивно-статические глаголы МСЯ без видовой парности могми бы считаться, с точки зрения славянского деривационного виАа, или Авувидовыми или несоотносительными глаголами НСВ. Но с точки зрения молизско-славянской системы они несомненно Авувидовые $(\mathrm{H} /$ СВ), причем флективная оппозиция имперфект : перфект определяет конкретные видовые функции, т.е. таким же образом, как в романских языках. Например, в предложениях (10) по (13), у глаголов kapit 'понимать/понять', vit 'видеть/увидеть', znat 'знать/узнать', а также jimat 'иметь/получить' перфект выражает начало действия, а имперфект выражает состояние после его начала, а также многократность ими хабитуальность:

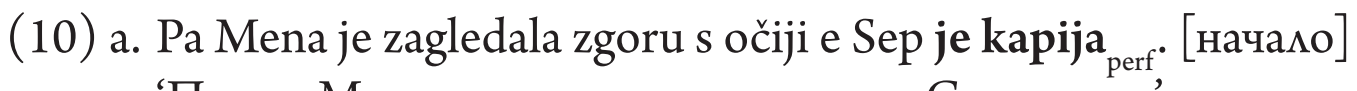
'Потом Мена закатила глаза наверх и Сеп поняк.'

6. Znadaša ka govorahu latalijana, ma kapahu ${ }_{\text {imperf }}$ pur na-našu. [состояние]

'Он знал, что они говорили по-итальянски, но они понимахи также по-молизско-славянски.'

B. Ju kapaša ${ }_{\text {imperf }}$ svedni, kada Mena mu pitaša štokodi sendza riči. [многократность]

'Он ее всегАа понимах, когда Мена спрашивала его о чем-либо без слов.'

(11) a. Je vidija ${ }_{\text {perf }}$ jiz naduga nu kobilu. [начамо] 'Он увидем изАали кобылу.'

6. $\neq$ Vidaše $_{\text {imperf }}$ jiz naduga nu kobilu. [состояние] 'Он видем изАали кобылу.'

8 Эти термины относятся к классификации мексических еАиниц в рамках теоретической модели интерактивного взаимодействия мексики с видом (аспектом) ИАА, ср. Брой 1997. 


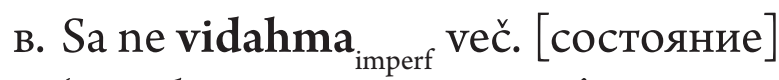
'Мы больше не виделись.'

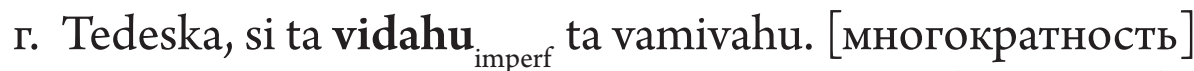
'КогАа немцы видели тебя, они тебя брали (= хватали).'

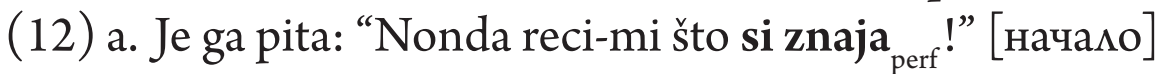
'Он его спросил: «ТогАа, скажи мне, что ты узнам!»

$\sigma \neq$ Je ga pita: "Nonda reci-mi što znadaša ${ }_{\text {imperf }}$ " [состояние; cp. также пример (106)]

'Он его спросил: «ТогАа, скажи мне, что ты знам!»

(13) a. Je jima $a_{\text {perf }}$ jenu konfermu do no ka mislaša, kada je poša na Palatu. [начало]

'Он получия подтвержАение того, что думац, когАа пошел в Памату'.

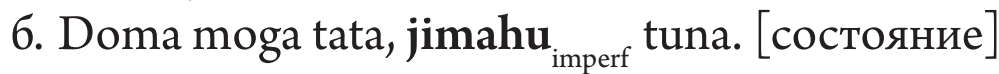
'Аома у моего отца, у меня бымо все.'

в. Don Vitorij do nje je jima ${ }_{\text {perf }}$ dva ditata, jena maskuli aš jenu feminu. Oni maskuli jimaša ${ }_{\text {imperf }}$ sedam gošti veča do sestre. [начало + состояние]

'Господин Виторий получия от нее два ребенка, одного мужского и оАного женского (пола). Мужской (= махьчик) бым на семь мет старше сестры.'

У глагола jimat 'иметь/получить' Ааже появился вторичный глагол НСВ jimivat с мексикализованным значением «начало». В имперфекте он выражает многократность начаца состояния, а также процесс в смысле 'он как раз получал.' Таким образом возникла видовая пара jimat/jimivat co значениями 'иметь, получить/покучать' в (14):

(14) a. Jena sam jimaša ${ }_{\text {imperf }}$ ovi don. [состояние] 'Только у одного быи этот аар.'

6. Jena sam je jima ${ }_{\text {perf }}$ ovi don. [начало] 'Только один получил этот Аар.'

в. Si bihu veča do jenoga neputa, jena sam ga jimivaša ${ }_{\text {imperf }}$ ovi don. [многократное начало]

'Если было больше оАного внука, только один (из них) получак этот Аар.' 
У глаголов, выражающие Аеятельности или состояния без начинательной характеристики, в перфекте НСВ Аоминирует Аелимитативная мимитация, т.е. временная ограничительность, например, в Авувидовых глаголах rabit 'работать/(поработать)' в (15a-6) и živit 'жить/(пожить)' в (16а), в то время как имперфект (НСВ) в (166) исключает ограничение. Поэтому имперфект rabahu 'они работали' в ограничительных контекстах примеров (15a-6) не быи бы возможен: ${ }^{9}$

(15) a. Su rabil ${ }_{\text {perf }}$ tuna jistru za skargat driv do nave. [Аелимитативность] 'Они работали всё утро, чтобы погрузить Арова на корабль.'

6. Su rabil ${ }_{\text {perf }}$ prije čeljade! [Аелимитативность] 'Раньше мюди работами!'

(16) a. Su živil ${ }_{\text {perf }}$ svedni u grad. [Аелимитативность] 'Они всегАа жими в Аеревне (в то время, о котором мы говорим)'.

6. $\neq \check{Z}$ 'ivahu $_{\text {imperf }}$ svedni u grad. [состояние]

'Они всега жими в деревне.'

С Аругой стороны, Аелимитативность не исключена и у инцептивно-статических глаголов как jimat 'иметь/получить' в (17a) и с̌ut 'чувствовать/ почувствовать' в (176):

(17) a. Oni vrima ka je sta u grad do žen je jima ${ }_{\text {perf }}$ veča do jene. [Аелимитативность]

'В то время, когда он бывал в деревне, что касается женщин, у него бымо больше одной.'

6. Sa čujam čuda dobra, kaka nisa sa maj čuja ${ }_{\text {perf }}$ utra moj život. [Аелимитативность]

'Я чувствую себя очень хорошо, как я никогАа не чувствовал себя в своей жизни.'

Инцептивное значение не ограничено состояниями в узком смысле. Есть, например, преАложения, как в пункте (18), в которых перфект НСВ

9 Точнее говоря, имперфект rabahu в (15a) был бы возможен только в том скучае, если бы речь шла о многократности демимитативного действия в смысле 'они всегАа работали все утро.... 
видовой пары ${ }^{10}$ hot/pokj 'ходить, ездить, идти, ехать/пойти, поехать', т.е. je hodija, указывает на начало Аействия, в то время как имперфект НСВ gredaša, как обычно, выражает процесс.

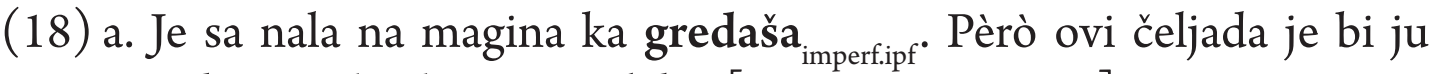
vidija e je hodija $a_{\text {perf.ipf }}$ palaka. [процесс + начало]

'Появилась машина, которая ехама. Но этот человек увидем ее и медленно.'

6. Dop ka su jimal dita, njifog život je hodija $a_{\text {perf.ipf }}$ napri kana oni do drugihi familji.

'После того, как они получили ребенка (= у них появился ребенок), их жизнь начала идти впереА, как (жизнь) у Аругих семей.'

Не только основные непредельные действия могут выражаться перфектом НСВ, но также и предельные действия. ОАнако в этом случае происхоАит абстрагирование от предела Аействия, т.е. возникает второстепенное непредельное действие. Чаще всего это встречается в случае неограниченной многократности, которая выражается при помощи несовершенного вида и ограничивается во временном плане с помощью перфекта. Так как многократность в этих случаях не очень отчетливо проявцяется, функция перфекта НСВ часто приближается к общефактическому значению; ср. предложения в (19):

(19) a. E ove su stvare ka su sučedival ${ }_{\text {perf.ipf }}$ nonda, do gvere. 'Вот вещи, которые скучались тогАа, на войне.'

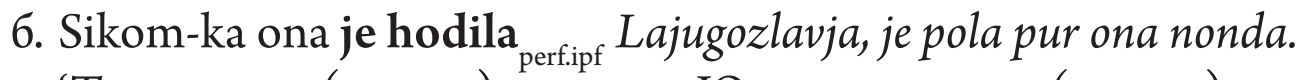
'Так как она (= мать) ездима в Югославию, она (= Аочь) тоже поехама туда.'

Речь иАет об обобщении событий, а не о конкретных процессах, которые выражались бы с помощью имперфекта НCB, т.е. sučedivahu вместо su sučedival и ' gredaša вместо je hodila, ср. (19a') и (196'):

10 Строго говоря, зАесь можно говорить и о видовой тройке, если принять во внимание тот факт, что в состав парадигмы этой мексемы входят также формы основы несовершенного вида gre-, а именно в имперфекте и настоящем времени, от которой, однако, не образуется ни инфинитив, ни перфект. Кроме того, особую роль играет основа несовершенного вила (j)id-, которая явмяется синонимом корня gre- в многократных ситуациях. 
(19) a'. E ove su stvare ka sučedivahu imperfipf $_{\text {nonda, do gvere. }}$ 'Вот вещи, которые происходили тогАа, на войне.' $6^{\prime}$.Sikom-ka ona gredaša ${ }_{\text {imperf.ipf }}$ Lajugozlavja, je pola pur ona nonda. 'Так как она (= мать) ехама в Югославию, она (= Аочь) тоже поехала туда.'

В предложении (20) перфект НСВ также выражает временно́е ограничение итеративной ситуации, в то время как имперфекты (Авувидового глагола или глагола несовершенного вида) rabahu и plačahu обозначали бы неограниченный временными рамками обычай:

(20) Pa kaka su rabil ${ }_{\text {perf }}$, su njimi plačival ${ }_{\text {perf.ipf }}$ $\neq$ rabahu $_{\text {imperf }} /$ plačahu $_{\text {imperf.ipf }}$ 'ТогАа по тому, как они работали, они им пматили.'

C Аругой стороны, существует возможность выражения не многократности отАельных действий, а их совокупности. ТогАа в перфекте возникает конкуренция виАов. Сравните преАложения в (21), которые следуют Аруг за Аругом в оригинальном тексте. В первом преАложении употреблен перфект НСВ nisu rivival, а во втором - перфект СВ nisu rival:

(21) a. Dòp dva o tri misaca... lista nisu rivival ${ }_{\text {perf.ipf }}$ več e tvoj tata je prisega Kundžetu.

'После Авух или трех месяцев... письма больше не приходими, и твой отец женился на КунАжете.

6. Benja nenadaša mangu on, zašto Nduneta nije mu pisala več o aje lista nisu rival ${ }_{\text {perf.pf }}$ več.

'Может быть, Ааже он сам не знац, почему НАунета ему больше не писала или почему письма больше не пришии.

Многократность может вытекать из внутренней структуры актантов. Например, в оригинальном преАложении (22a) перфект НСВ, по утвержАению носителей языка, указывает специально на тот факт, что местница состоит из множества перекцаАин, с помощью которых мюАи поднимаются. Несмотря на то, что речь зАесь идет о цепи действий, употребляется HCB sa sa penja 'я поднимался'; таксисная ситуация последовательности Аействий выражается при помощи перфекта. В таких скучаях, наряду с 
перфектом НСВ, также возможен перфект СВ, без указания на множество перекладин, как в варианте (226). ${ }^{11}$

(22) a. Sa vaza nu pilu e sa sa penja ${ }_{\text {perf.ipf }}$ škala do sufite, sa poša gor. 'Я взял фонарь и поднимался (!) по чердачной местнице, я пошем наверх.'

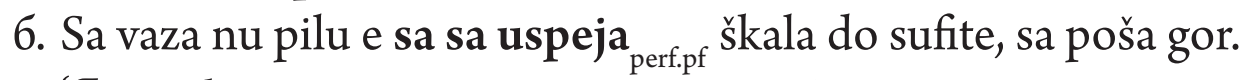
'Я взял фонарь и поднялся по чердачной местнице, я пошел наверх.'

В то время как временное ограничение выражается всегда с помощью перфекта НСВ, количественное ограничение выражает обычно перфект $\mathrm{CB}$, как в примере (23):

(23) Je doša ${ }_{\text {perf.pf }}$ pe-šast voti utra ve trendačing an.

'Он пришек пять, шесть раз в течение этих 35-ти кет.'

Но когАа речь идет не о суммарном, а о более неопределенном количестве, вновь употребляется перфект НСВ с его функцией временного ограничения многократности; ср. примеры в (24) и (25):

(24) Čuda voti su nasa pitival ${ }_{\text {perf.ipf }}$ tedeska. 'Много раз нас спрашивахи немцы.'

(25) Oni pa je nasa salviva $a_{\text {perf.ipf }} s$ manaštrom čuda voti. 'Тогаа он спасал нас много раз супом.'

Перфект НСВ может также выражать результативное значение, а именно, когАа речь идет о дистрибутивных или повторяющихся результатах, как в (26) и (27):

(26) Saki dan ka sa vrače do mora... prodava ribe friške ka je piskiva $_{\text {perf.ipf }}$.

'КажАый Аень, когда он возвращается с моря... он продает свежую рыбу, которую он поймал [Аосл. свежие рыбы, которые он мовим].'

11 И вновь следует обратить внимание на тот факт, что перфект НСВ никогда не выражает процесс, т.е. речь зАесь не может иАти просто о процессе, протекающем на мюбой местнице. Процессуальная функция обязательно требовала бы имперфекта HCB sa penjahu, который, с Аругой стороны, исключен в контексте цепи Аействий $(22 \mathrm{a} / 6)$. 
(27) One su dža jimival ${ }_{\text {perfipf }}$ so.

'Они (= кажАый стручок перца) уже получили [Аосл. покуча$\mathbf{\Lambda и ] ~ с о л ь ' . ~}$

\section{2. Имперфект совершенного виАа}

Перейдем теперь к имперфекту СВ, Аругой противоречивой комбинации видовых граммем в МСЯ. С общеславянской точки зрения интересно, что эта комбинация, которая сохранилась также в болгарском и макеАонском языках, отсутствует как в сербохорватских диалектах на балканском полуострове, так и в Аитературных языках этой группы.

\subsection{1. Итеративность}

Как бымо указано выше, имперфект не позвомяет ограничение, мимитацию. Из этого следует, что мимитативная функция СВ здесь не может появиться на синтаксической поверхности преАложения. Она уходит на второй план, на уровень «микротекста», который явмяется компонентом неограниченного «макротекста» на поверхности. ${ }^{12}$ Самым частым скучаем такого подчинения значения предельных глаголов СВ макротексту, выраженному с помощью имперфекта, явмяется неограниченное повторение таксисных конструкций, прежде всего в форме хабитуальной цепи действий, как в примерах (28) и (29): ${ }^{13}$

(28) Pa ga ponesahmo imperf.pf $_{\text {u vod na rik. Ume vode vržahmo }}$ imperf.pf ovi lan, ove faše.

'Потом мы несли [Аосл. понесли] его к воде в реке. Мы клали [Аосм. поможили] в воАу этот мен, эти пуки.' (ММ)

12 О понятиях «микротекст» и «макротекст» (или «micro-level, macro-level») cp. Stunová 1986 и Breu 2000, 42-51. Употребление имперфекта СВ в МСЯ во многом похоже на его функции в болгарском и македонском языках, в том числе в случае итеративности, но есть и разАичия; о функциях имперфекта в этих языках ср., например, Станков 1966 и Конески 1982, 426-430.

13 Так как в русском нет имперфекта, выбор глагольных форм в русском переводе затруднен. В Аальнейшем имперфект СВ, обозначающий повторение, будет перевоАиться с помощью прошеАшего НСВ, с Аобавлением в скобках прошеАшего СВ, более близкого по виАу. Аругой возможностью явмяется перевоА с помощью нагляАно-примерной конструкции типа «бывамо так + настоящее $\mathrm{CB} \gg$. 
(29) Pa ona voda se arkulaše imperf.pf $_{\text {e se vržaše }}$ imperf.pf $_{\text {varit. }}$ 'Потом эта вода вытекала [Аосл. вытекла]' и ставилась [Аосл. поставимась] кипеть.' (ММ)

Имперфект СВ в таких преАложениях можно, правАа, заменить, имперфектом НСВ, но тогАа могла бы возникнуть омонимия межАу значением хабитуальной цепи Аействий и Аругими таксисными ситуациями, например, ^окализованной или хабитуальной полной одновременностью Аействий, которую имперфект СВ искмючает.

С Аругой стороны, Аействия, выраженные с помощью имперфекта $\mathrm{CB}$, не всегАа обозначают следование одного Аействия за Аругим. Например, в (30) речь идет о повторении альтернативных Аействий:

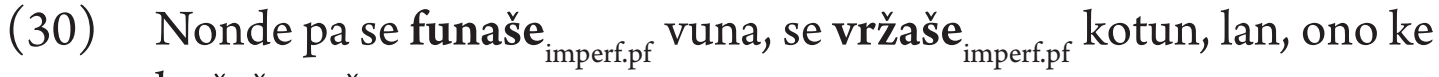
hočaše vrč.

'Там погружалась [Аосл. погрузимась] шерсть, закладывался [Аосл. вложияся] хлопок, мен, то, что ты хотел заложить.' (ММ)

Наряду с хабитуальными действиями, имперфект СВ выражает также и Аругие типы неограниченной итерации, например, неограниченную итерацию цепи действий в мокализованной ситуации (31a). В примере (316), из такой актуальной итерации микротекста в макротексте Ааже вытекает непредельный второстепенный процесс:

(31) a. Funaše imperf.pp $_{\text {čnit večer, e jutrim mu padaše }}$ imperf.pf ga najaše $_{\text {imperf.pf }}$ paduti.

'(В то время как он строия эту стену, было всегда так:) Он заканчивац [Аосл. закончик] строить вечером, а утром (она) у него падала [Аосл. упала], он находиц [Аосл. нашек] ее упавшей.'(MМ)

6. Kada mu rivahu imperf.pf kurt, oni s' ga udjaše imperf.pf putem do kambisanda.

'КогАа (= по мере того, как) они к нему (= барану) приближамись [Аосл. приблизимись], он (все снова) убегал [Аосл. убежам], по Аороге к кмадбищу.'

Хотя в Аанных случаях мы часто встречаем больше одного имперфекта CВ Аля выражения неограниченной многократности, в сущности, Ао- 
статочен один из них. Например, в (32а) есть только один имперфект $\mathrm{CB}$, а именно имперфект глагола dokj 'прийти'. В (326) Ава имперфекта СВ ponesahu и skargahu соединяются с имперфектом НСВ vamivaša и с Авувидовым имперфектом maša, из которых vamivaša входит в состав предельной видовой пары vamivat/vazet. 3Аесь можно было бы заменить имперфект НСВ vamivaša имперфектом СВ vamjaša, без изменения значения преАложения.

(32) a. Moj tata, bonoču maša stat kurta njevga cila e ovdan dojaša ${ }_{\text {imperf.pf }}$ van.

'И мой отец ночью Аолжен быц оставаться у своего Аяди, а Анем он приходик [к нам; досл. пришек] на поле.'

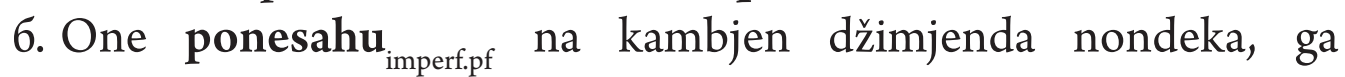
skargahu $_{\text {imperf.pf }}$ vana, e ti nonda vamivaša ${ }_{\text {imperf.jpf }}$ sakate, maša $_{\text {imperf }}$ nosi po fabriku.

'Они везми [Аосм. повезми] на грузовике цемент туда, разгружали [Аосл. разгрузими] его на улице, а ты, там брам мешки, ты домжен бым носить их по заводу'

В случае если многократная цепь действий только имплицитнта, т. е. вне явной таксисной ситуации последовательности, имперфект СВ встречается также и у изолированных глагольных Аействий, хотя и Аовольно реАко, например, у мексемы govorat/reč 'говорить/сказать' в (33а-б). В (33в) речь идет Ааже об актуальной (локализованной) итерации. Мы встречаем такое употребление имперфекта СВ прежде всего в говорах деревень Монтемитро и Сан Феличе. Но, в принципе, итеративное употребление имперфекта СВ вне явной цепи действий возможно также в говоре Аквавивы, ср. пример (33г):

\footnotetext{
(33)a. «Mam tuč, » vaka sa rečaša ${ }_{\text {imperf.pf }}$ «mam tuči djavulil». (CФ) '《Я АОлжен Аавить,» так говорилось [Аосл. скамазось] «я Аомжен Аавить перец»'.

6. To su sve stvare ke rečahu imperf.pf $_{\text {pri. }}$ pri. 'Это всё вещи, которые (АюАи) говорили [Аосл. сказами] раньше. (МM)
} 


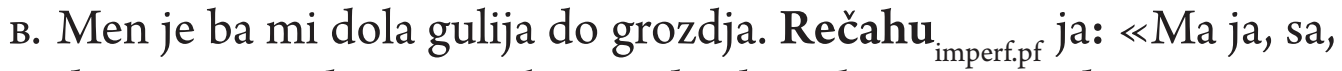
di mam po nabra no malo grozdja, ke ja hočem grozdje?»

'Мне захотелось поесть винограда. Я говорил (= постоянно Аумал; Аосл. сказал): «Но, гАе я могу теперь собрать немного винограда, потому что я хочу винограА? ’’ (MМ)

г. Saku nelju dan mi umbraša ${ }_{\text {pres.pf }}$ na ovca. 'КажАую неделю у меня умирала [Аосл. умерма] овца.'

\subsection{2. Условные конструкции (ирреальность и потенциальность)}

Аругой важной функцией имперфекта СВ, наряду с процитированными случаями итеративности, явмяется его употребление в ирреальных, контрафактических конструкциях, причем, как в главном, так и в подчиненном преАложении, сравните (34):

(34) Si mi rečahma ${ }_{\text {imperf.pf }}$, dič: «Nò, mi ... », one, zgora, dojahu ${ }_{\text {imperf.pf }}$ $s$ jenme kararmatam a nasa čakivahu tuna!

'Если бы мы сказами, дескать: «Нет, мы ... », тогАа они, сверху, приехами бы на танке и убили [Аосл. разАробили] бы нас всех.'

В этом скучае проявилось, по всей вероятности, влияние контактных разновидностей итальянского языка. ${ }^{14}$ Как и в имперфекте этих разновидностей,

14 Также и здесь речь иАет о разговорной разновидности итальянского и о Аиалектах, в то время как имперфект стандартного итальянского языка не имеет ирреальную функцию; cp. Rohlfs $(1969,146-147)$, например: sə mma chiamivo $\partial_{\text {imperf }}$ er ${ }_{\text {imperf }}$ chiú mmejja (Абруццы) $\neq$ se mi avessi chiamato ${ }_{\text {papsbsi }}$ sarebbe stato ${ }_{\text {cond }}$ meglio (станаарт) ${ }^{\text {imperf }}$ 'Если бы он меня призвал, было бы кучше.' Как известно, имперфект в усмовных конструкциях встречается также в болгарском и макеАонском. Но надо обратить внимание на тот факт, что в этих языках ирреальное употребление имперфекта в сущности ограничивается приАаточными преАложениями, в то время как в МСЯ как и в итальянском такого ограничения нет. В связи с этим внутриславянское развитие, параллельное напр. болгарскому, в этом скучае не кажется правдоподобным, несмотря на общую тенденцию имперфекта к сфере ирреальности, которая вытекает именно из его употребления в (подчиненных) условных преАложениях названных языков. ПравАа, имперфект также употребляется иногАа в болгарских главных преАложениях с модальной функцией. Но тогАа речь идет об экспрессивном, например, оптативном употреблении, которое проистекает, по-видимому, из его употребцения в приАаточных преАложениях; ср. Станков $(1966,135-136)$ и Стоянов $(1983,333-335)$. Также и в македонском ирреальное употребление ограничивается главным образом приАаточным преАложением, хотя в особенных случаях (отрицание) оно иногда встречается и в главной части условной конструкции, по крайней мере в отАельных диалектах; ср. Гајдова (2008, 
в МСЯ невозможно размичение межАу хабитуальностью и ирреальностью на уровне грамматических форм имперфекта. Например, dojahu может обозначать как 'они (обычно) приезжали', так и 'они приехали бы.

Аругие примеры, в которых без специального контекста невозможно размичить контрафактическую гипотезу и реальную хабитуальность, Ааны в пункте (35): ${ }^{15}$

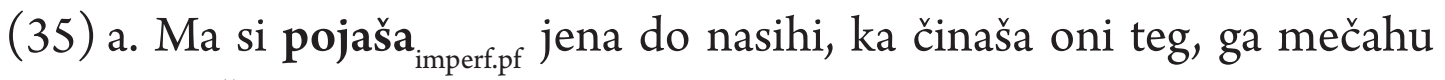
paržuna.

'Но если бы пошел один из наших, который саелал бы такое Аело, то его посадили бы в тюрьму' || 'если ходиц... Аелац... сажали'

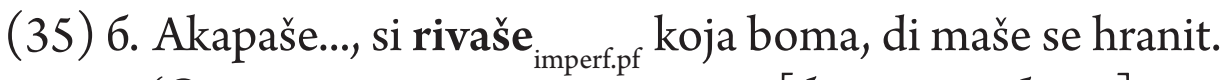
'Он понимал... если падала [букв. прибыма] какая-нибудь бомба, гАе он Аомжен был прятаться.' || 'прибыма бы' (MМ)

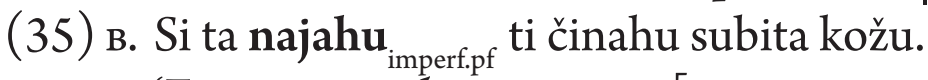

'Если они тебя находими [Аосл. нашии], они тебя сразу убивами.' || 'нашии бы - убими бы'

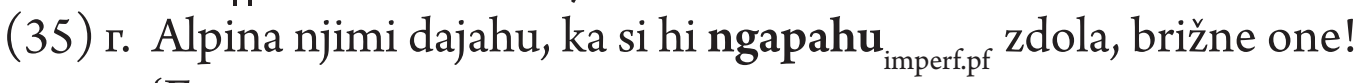
'Горные стрелки им Аавали, потому что, если они на них попаАались [Аосл. попамись ], беАняги они!' || 'попамись бы'

Проблема омонимии межАу ирреальностью и хабитуальностью встречается также в преАложениях без условного союза как в следующем примере:

(36) Za poni sekolicimi maše goni binoč, ajer-ke jutrim idjahu sikolic

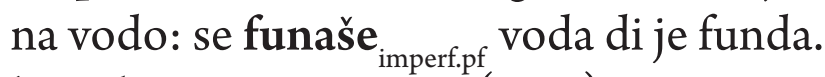

'Чтобы привезти всем (воду), он Аолжен был везти (ее) ночью, потому что Утром все Ходили за воАой: воАа в колоАце иссякама.' || 'иссякиа бы’. (ММ)

154). В противоположность этому, в МСЯ имперфект совершенно свободно выражает ирреальность в главных предложениях, Ааже в изолированных контрафактических преАложениях типа ti moraša ${ }_{\text {imperf }}$ dokj sam 'ты мог прийти сам (т.е. «без твоего Аруга; почему ты не пришел? »)', ровно так же, как и в разговорном итальянском: tu potevi imperf venire da solo.

15 В этих примерах сначала Аается перевод со смыслом, вытекающим из контекста оригинала, а потом соответствующий альтернативный перевоА, возможный в изолированном преАложении. 
Ирреальность может выражаться также с помощью имперфекта НСВ, прежде всего с непредельными глаголами как kumbinivat в (37a). Но как подтвержАает пример (376) с мексемой trabukat/trabukivat 'перевернуться/перевертываться', имперфект НСВ употребляется как вариант также при предельных действиях. Молодые носители языка его Ааже преАпочитают. Впрочем, этот пример показывает, что в случае контрафактического условия возможен также кондиционалис типа «bi+причастие на $-l \gg$ :

(37) a. Si oni ne kumbinivaša ${ }_{\text {imperf.jpf }}$, lor ti moraša ${ }_{\text {imperf }}$ reč: «Vamivam ja za štisi prec».

'Если бы он не граничим (с этим участком земли), то ты мог бы сказать: «Я беру (= возьму) землю за ту же самую цену».'

6. Pur si sa trabukivahma imperf.pf $^{\ldots}$ o bi sa salvala cond.pf o bi umbrala ${ }_{\text {cond.pf }}$

'Ааже если бы мы переворачивались... она или спаслась бы ими умерма бы.'

Потенциальное условное преАложение, которое в противоположность ирреальной контрафактической гипотезе указывает на исполняемое усмовие, также выражается обычно имперфектом СВ: ${ }^{16}$

(38) Si surtaša ${ }_{\text {imperf.pf }}$ štokodira ovoj krijaturi, pa umbraša imperf.pf $_{\text {ova }}$ krijatura sendza kersti.

'Если бы скучимось (в буАущем) что-нибудь с этим ребенком, тогАа этот ребенок умер бы без крещения.' (СФ)

В темпоральных сложноподчиненных преАложениях имперфект СВ оАнозначно обозначает итеративность, как в (39), в то время как в скучае мокализованности в прошлом обязательно употреблялся бы, как и следовало ожидать, перфект СВ (sma ostal, su vazal, su ponil):

16 В этом случае также не искиючен имперфект НСВ. Необходимо обратить внимание на тот факт, что в (разговорном) итальянском индикативный имперфект на условном уровне ограничивается контрафактическими гипотезами. Поэтому расширение функций имперфекта на потенциальные гипотезы явмяется, по всей вероятности, внутриязыковым развитием МСЯ, основывающимся на полисемической модели славянского кондиционалиса типа јa bi umbra 'я бы умер' (потенциальное и контрафактическое значение); cp. Breu 1999, 248-251. 


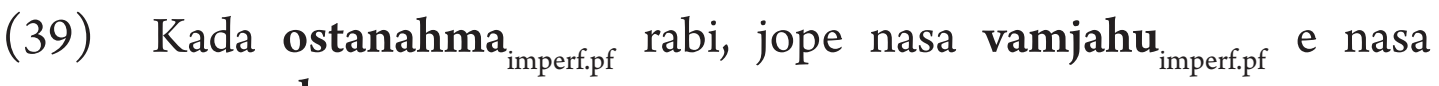
ponesahu $_{\text {imperf.pf }}{ }^{\circ}$

'КогАа мы прекращали [Аосл. прекратили] работать, нас опять схватывали [Аосл. схватими] и нас увозили [Аосл. унесли].'

Но если речь идет о локализованном «будущем в прошлом», употребляется имперфект НСB:

(40) Su tuna minal, ke, kada rivivaša ${ }_{\text {imperf.ipf }}$ frond rus, mahu skača palariju.

'Они все заминировали, чтобы, когАа приАет [Аосл. приходик] русский фронт, они бы взорвали (это) в возАух.’

\subsection{3. Таксисная ситуация следования с союзом prije-ka}

В зависимой части сложноподчиненного преАложения с союзом prije$k a$ 'перед тем как, прежде чем', который выражает таксисную функцию (нейтрального) следования, употребляется обычно имперфект НСВ, в том числе в мокализованных, однократных ситуациях, как в примере (41a) с мексемой partit/parčivat 'отправиться/отправмяться'. Хотя в текстах в наших корпусах мы нашии вместе с союзом prije-ka только эту комбинацию видов, новейшие исследования показали, что возможен также имперфект СВ. Некоторые носители молизско-славянского языка старшего поколения иногАа Ааже преАпочитают эту форму; ср. вариацию в примере (416) с мексемой kalat/kalivat 'зайти/заходить'. Но перфект CB, который следовало бы ожидать с общеславянской точки зрения, и у них искиючен: ${ }^{17}$

17 Употребление имперфекта (обоих видов) с союзом prije-ka в мокализованных ситуациях, вместо перфекта СВ, явмяется особенностью МСЯ, вызванной языковым контактом с итальянским языком и его Аиалектами; ср. Брой (в печати, гл. 1.3.1.2.2), гАе, оАнако, привоАятся только примеры с имперфектом НСВ. В итальянском союз prima che 'переА тем, как' управмяет в прошедшем времени конъюнктивом имперфекта. Так как в МСЯ такого конъюнктива нет, он заменяет его соответствующим изъявительным имперфектом. Например, предложение (416) перевелось бы: Ѐ arrivato prima che calasse $_{\text {imperf.sbj }}$ il sole. 
(41) a. Je vaza baližu e je sa skinija, jušt jušt prije ka tren parčivaša ${ }_{\text {imperf.ipf }}$ jopa.

'Он взял чемодан и сошел, точно переА тем, как поезА снова отправился [Аосл. отправмялся].'

б. Je doša prije-ka kalaša imperf.pf $\sim$ kalivaša $_{\text {imperf.pf }}$ sundza. 'Он пришел перед тем, как зашио ( заходимо) солнце.'

Итак, имперфект СВ употребляется в (416) с союзом prije- $k a$ в мокализованной ситуации, в то время как в Аругих вышеупомянутых индикативных примерах он всегАа выражает многократность. С Аругой стороны имперфект СВ в зависимой части сложноподчиненного преАложения с этим союзом также возможен и при повторении, как в (42), в Аанном случае в комбинации с имперфектом НСВ в главной части оригинального преАложения. ЗАесь также можно было бы заменить оба имперфекта формами Аругого виАа, kalivaša ${ }_{\text {imperf.jpf }}$ и vamjahu $u_{\text {imperf.pf }}$, без изменения значения:

(42) Prije-ka kalaša imperf.pf $_{\text {sundza, vamivahu }}$ imperf.ipf vodu di puč. 'ПереА тем, как заходило солнце [Аосл. зашио], я брам воду у колодца.'

\section{3. Настоящее совершенного виАа}

Третьей комбинацией видовременных граммем, которую мы еще вкратце рассмотрим, явмяется настоящее СВ. В отличие от русского и точно так же как в хорватском, ${ }^{18}$ у настоящего СВ в МСЯ нет функции будущего.

\subsection{1. Итеративность}

Как показывает предложение (43), настоящее $\mathrm{CB}$, точно так же как имперфект СВ, выражает на языковой поверхности неограниченную многократность цепи действий, с указанием на однократную послеАовательность ситуаций на уровне (подчиненного) микротекста:

(43) Vamjaš ${ }_{\text {pres.pf }}$ grozja, nosiš doma, vamjaš ${ }_{\text {pres.pf }}$ maginu, jamivaš grapola, ostava zrnj skvačani, ga mečaš utra butina.

18 О функциях настоящего времени СВ ср., например, Mihajlovic 1962. 
'Ты берешь [Аосл. возьмешь] грозди винограда, несешь (их) Аомой, берешь [Аосл. возьмешь] машинку, убираешь выжимки, остается черный винограА, ты его кмадешь в баки.'

Как видно из этого преАложения, в этой функции также возможны несовершенные глаголы (jamivaš, ostava, mečaš). Присутствие хотя бы оАной формы настоящего СВ Аостаточно, чтобы исключить интерпретацию форм НСВ в смысле оАновременности актуальных Аействий.

ПредыАущий результат итеративных Аействий, выраженных с помощью настоящего СВ, обычно выражается с помощью перфекта СВ, как в (44), с его перфектно-результативной функцией: ${ }^{19}$

\section{(44) Ka maslina je sa ngalala ${ }_{\text {perf.pf }}$, pa ngapa ${ }_{\text {pres.pf }}$ 'КогАа маслина согремась, тогАа она скисает [Аосл. скиснет].'}

\subsection{2. Условные и темпоральные конструкции}

Настоящее СВ употребляется также в зависимой части сложноподчиненных преАложений с реальным условием, как в примерах (45a) и (456), и с мокализованной темпоральной последовательностью, как в примере $(45 \mathrm{~B})$.

(45) a. Si vamjaš ${ }_{\text {pres.pf }}$ kartu džeografik, češ ga pur na fut.pf . 'Если ты возьмешь географическую карту, ты даже найдешь его.'

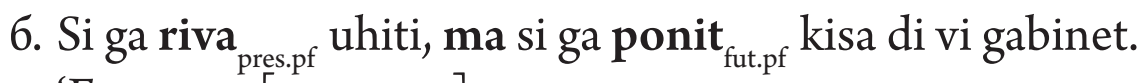
'Если ему [= поезАу $]$ уаается зацепить его, он понесет за собой этот туалетный Аомик куАа бы то ни было.'

B. Ka doje pres.pf $_{\text {kf }}$ kapofabrik, čma vit fut što govare.

'КогАа придет директор завода, мы увидим, что он скажет [Аоси. говорит].'

ГАавная часть СПП содержит в этих примерах форму будущего, ${ }^{20}$ а речь идет об однократных ситуациях в будущем. Но если главная часть СПП

19 Как было упомянуто выше, в случае множества отдельных результатов, употребляется перфект НСВ; см. пример (26).

20 МСЯ имеет Ава типа будущего, «будущее вероятности» (futurum probabilitatis), образуемое с помощью вспомогательного глагола tit 'хотеть', как с̌еš na (45a) и с̌ma 
тоже содержит настоящее СВ, как в примере (46а) с настоящим СВ глагола bit 'быть', или же настоящее НСВ, как в (466), тогАа появмяется значение многократности ситуации:

(46) a. Ona, kada dodje pres.pf $_{\text {ode, bide }}$ pres.pf $s$ nami, govore nako, kano ja oš ti.

'КогАа она приходит [Аосл. придет] сюАа, она бывает [Аосл. будет] с нами, она говорит так, как я и ты.' (MМ)

6. Kada kučak počme pres.pf $_{\text {dust, ti nenadeš }}$ pres.ipf maj kada tartuf... si je zgora zgora, si je zdola, čuda zdola. MM

'КогАа собака начинает [Аосл. начнет] рыть, ты никогда не знаешь, когАа трюфель ... находится ми он на самой поверхности, находится ми он внизу, в самом низу'.

В общем и целом, это означает, что настоящее СВ в зависимой части СПП может относиться мибо к оАнократной, мибо к многократной ситуации, в то время как настоящим СВ в главной части СПП оАнозначно определяется многократный характер Аействий.

\subsection{3. Особенные употребления}

Как в имперфекте, так и в настоящем иногАа встречаются изолированные формы СВ, которые выражают хабитуальность (вторичное состояние), прежде всего в ММ и СФ:

(47) Nak se zove oni brdo ke doje pres.pf $_{\text {zdolo. }}$

'Так называется тот холм, который спускается [букв. придет] вниз. (ММ)

Надо обратить внимание на тот факт, что настоящее СВ в МСЯ обычно не употребляется в историческом настоящем, т.е. в принципе так же как в русском, но в отличие от хорватского языка. Сравните пример исторического настоящего НСВ в (48) с предельными мексемами:

vit (45в), и «будущее необходимости» (futurum necessitatis), образуемое с помощью вспомогательного глагола jimat 'иметь', как ma ponit в (456); ср. Брой (в печати, I.4.4). 
(48) Kaka riviva $a_{\text {pres.ipf }}$ zdola Palate, po onu dišezu, sa štokiva ${ }_{\text {pres.ipf }}$ fren. 'КогАа он прибывает к подножью Аеревни Палата, у этого уклона, обрывается тормоз (велосипеАа).'

ОАнако, историческое настоящее $\mathrm{CB}$ всё же возможно, хотя и реАко, в особенности в комбинации с имперфектом СВ, как в СПП (49) с хабитуальным значением:

(49) Kada dojahu imperf.pf $_{\text {bombardamenda, je prealarm ka pa ngopa }}$ pres.pf lalarm.

'КогАа наступают [Аосм. пришли] бомбардировки, объявмяется [Аосл. есть $]$ предупреАительная тревога, и потом объявмяется [Аосл. объявится] тревога.'

Следует добавить, что настоящее СВ также встречается в оптативных конструкциях с частицей neka 'пусть':

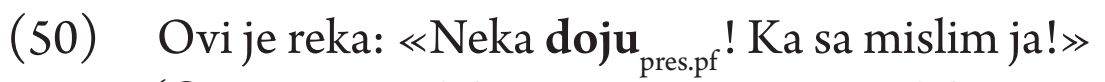

'Он сказал: «Пусть только придут! Потому что теперь этим буду заниматься я [Аосл. Потому что теперь думаю я].'

\section{4. ВиА глагола в Аругих микроязыках в контакте}

Поскольку объем статьи не позволяет подробного сравнения молизскославянских неоднородных видовых комбинаций с Аругими славянскими микроязыками в ситуациях интенсивного языкового контакта, я ограничусь Аишь некоторыми сведениями. Сравнивая, например, Аругие Ава микроязыка в проекте Euroslav2010,21 а именно бургенландско-хорватский язык в Австрии и верхнекужицкий разговорный язык в Германии с молизско-славянским языком, можно распознать как парамееи, так и размичия.

\section{1. БургенцанАско-хорватский микроязык}

В бургенцандско-хорватском микроязыке, нет ни имперфекта, ни аориста. ${ }^{22}$ Есть только прошеАшее на $-l$ обоих видов. В противоположность

21 Из этого корпуса взяты следующие примеры; ср. Adamou и Ap. 2013.

22 О грамматических особенностях бургенцандско-хорватских Аиалектов ср., например, Neweklowsky 1978, 194-217. 
молизско-славянскому и точно так же как в русском и хорватском, перфект НСВ зАесь выражает также и мокализованные процессы, состояния и все типы многократности. С Аругой стороны, настоящее СВ употребцяется почти обязательно в случае неограниченной многократности предельных действий, а именно не только в цепях действий, как обычно в молизско-славянском, но и в изолированных глаголах, где в МСЯ эта форма встречается только изреАка:

(51) Onda dopuodne duojdedu $u_{\text {pres.pf }}$ si guosti. 'Тогда Ао обеда [обычно] приходят [Аосл. придут] все гости.'

Поскольку в бургенцандско-хорватском нет имперфекта СВ, Аля выражения неограниченной многократности в прошлом образовацась специальная конструкция со вспомогательным глаголом tit + инфинитив:

(52) Pa je se tilo kuose splies.

'ТогАа (обычно) плелись косы [Аосл. хотелось сплести косы].'

Эта перифраза, очевидно, с типологической точки зрения соответствует английской перифразе типа I would go, но так как в немецком контактном языке такой конструкции нет, ${ }^{23}$ контактное вмияние этого языка при развитии бургенцандской конструкции искАючается.

В отличие от молизско-славянского, где такое употребление встречается очень реАко, и точно так же как в хорватском стандартном языке, настоящее СВ бургенлаАско-хорватского обладает также функцией исторического настоящего:

(53) Onda vračitel zame ${ }_{\text {pres.pf }}$ iz taške neki štetoskop.

'Тогда врач берет [Аосм. возмет] из сумки какой-то стетоскоп.'

4.2. Верхнекужицкий разговорный язык

Что касается верхнекужицкого разговорного языка, то он во многом отмичается от верхнекужицкого митературного языка, кроме прочего, и в

23 Эта конструкция отсутствует также в стандартных языках сербохорватской (БСХ) группы. 
видовой системе. ${ }^{24}$ Верхнелужицкий митературный язык является еАинственным северно-славянским языком, который сохранил фмективные формы прошеАшего, пусть только в непротиворечивых комбинациях с Аеривационным видом. Иными словами, в верхнекужицком нет имперфекта СВ (и аориста НСВ). Кроме того, перфект может заменить синтетические формы во всех их функциях, точно также как это происходит в немецком контактном языке. А в верхнекужицком разговорном языке фмективные формы почти совсем исчезли.

В деривационной видовой системе этой бытовой разновидности произошли очень сильные изменения. В общем и целом можно сказать, что оппозиция цемостности превратилась в оппозицию грамматической преАельности (Breu 2005, 61-65). Это значит, кроме прочего, что настоящее СВ может выразить актуальные предельные процессы и повторение преАельных действий, а настоящее НСВ выражает непредельные процессы, состояния и кратность непредельных действий; ср. преАложения в (54) с настоящим СВ, выражающим актуальное предельное Аействие в (54а) и многократное предельное Аействие в (546):

(54) a. Ale běše pola jeno druho jězora, dókejš so tam, něšto ponowi $\mathbf{p}_{\text {pres.pf }}$ po to jězora.

'Но это было у Аругого озера, так как там (как раз) что-то обновляют [Аосл. обновится] у этого озера.'

6. Ha tam sej mó pon šece naše deki połožimo ${ }_{\text {pres.pf }}$. 'И там мы стелим [Аосл. положим] всегАа наши одеяла.'

Уже из данных примеров явствует, что приведенные здесь славянские микроязыки развивались по-разному в языковом контакте с неславянскими языками. Кажется, только отчасти изменения происходят из-за непосреАственного влияния доминантного контактного языка, наряду с внутриязыковыми изменениями. Эта область обязательно требует Аальнейших специальных исследований, например, на основе устных текстов корпуса EuroSlav 2010.

24 О грамматических особенностях верхнекужицкого разговорного языка cp. Scholzе 2008 и Breu 2005. 
Сокращения (гмоссы)

\begin{tabular}{l|l} 
cond & кондиционалис \\
\hline imperf & имперфект \\
\hline perf & перфект \\
\hline fut & будущее время \\
\hline pres & настоящее время \\
\hline pqp & плюсквамперфект \\
\hline ipf & несовершенный виА \\
\hline pf & совершенный виА \\
\hline sbj & конъюнктив (сослагательное накмонение)
\end{tabular}

\section{Аитература}

Брой, В. 1997. «Семантика глагольного вида как отвлечение от предемьных свойств мексем. (иерархическая модель компонентов)». В кн. С. Кароляк (отв. реА.), Семантика и структура славянского вида. II. Kraków: Wydawnictwo Naukowe WSP, 49-72.

- 2006. «Фмективный и Аеривационный глагольный виА в молизско-славянском языке». Вопросы языкознания 3:70-87.

_- (в печати). «Категория таксиса в молизско-славянском языке». В кн. В. С. Храковский, А. Барентсен, отв. реА., Категория таксис в славянских языках. Санкт-Петербург: Российская Академия наук.

Гајдова, У. 2008. Условниот период во дијалектите на македонскиот јазик. Скопје: Институт за македонски јазик «Крсте Мисирков».

Конески, Б. 1982. Граматика на македонскиот митературен јазик. Аел I и II. Скопје: Култура.

Станков, В. 1966. Имперфектьт в съвременния български книжовен език. София: Бъмгарска академия на науките.

Стоянов, С. , отв. реА. 1983. Граматика на съвременния бъцгарски книжовен език. Том 2, Морфология. София: Бъмгарска академия на науките.

Храковский, В.С., отв. реА. 2009. Типология таксисных конструкиий. Москва: Знак.

Adamou, E. and W. Breu. 2013. "Présentation du programme Euroslav 2010. Base de données électronique de variétés slaves menacées dans des pays européens non slavophones". In Deutsche Beiträge zum 15. Internationalen Slavistenkongress Minsk 2013, edited by S. Kempgen, M. Wingender, N. Franz, and M. Jakiša. München: Otto Sagner, 13-23. 
Adamou, E., W. Breu, G. Drettas, and L. Scholze. 2013. EuroSlav 2010 - Elektronische Datenbank bedrohter slavischer Varietäten in nichtslavophonen Ländern Europas Base de données électronique de variétés slaves menacées dans des pays européens non slavophones (Deutschland - Italien - Österreich - Griechenland). Paris: Lacito, Konstanz: Universität. http://lacito.vjf.cnrs.fr/archivage/index.htm\#europe .

Breu, W. 1994. "Interactions between Lexical, Temporal and Aspectual Meanings". Studies in Language 18:23-44.

1997. "Italienisch : Kroatisch (162)" In Kontaktlinguistik. Ein internationales Handbuch zeitgenössischer Forschung. 2. Halbband, edited by H. Goebl, P. H. Nelde, Z. Starý, and W. Wölck. Berlin, New York: Walter de Gruyter, 1362-1366. __ 1999. "Der Konditional im Moliseslavischen. Ein Beitrag zur Kontaktlinguistik”. In Ars Philologica. Festschrift für Baldur Panzer zum 65. Geburtstag, edited by K. Grünberg and W. Potthoff. Frankfurt a.M. etc.: Peter Lang, 243-253.

_ 2000. "Zur Position des Slavischen in einer Typologie des Verbalaspekts (Form, Funktion, Ebenenhierarchie und lexikalische Interaktion)". In Probleme der Interaktion von Lexik und Aspekt (ILA), edited by W. Breu. Tübingen: Niemeyer, 21-54.

__ 2005. "Verbalaspekt und Sprachkontakt. Ein Vergleich der Systeme zweier slavischer Minderheitensprachen (SWR/MSL)”. In Slavistische Linguistik 2003, edited by S. Kempgen. München: Otto Sagner, 37-95.

Breu, W. and G. Piccoli 2011/2012. Südslavisch unter romanischem Dach. Die Moliseslaven in Geschichte und Gegenwart im Spiegel ihrer Sprache. Teil I. Texte gesprochener Sprache aus Acquaviva Collecroce. Teil II. Texte gesprochener Sprache aus Montemitro und San Felice del Molise. München, Berlin, Washington (D.C.): Otto Sagner.

Ivić, P. 1958. Die serbokroatischen Dialekte. Ihre Struktur und Entwicklung. I. Allgemeines und die štokavische Dialektgruppe. 's-Gravenhage: Mouton \& Co.

Mihajlovic, M. 1962. Tempus und Aspekt im serbokroatischen Präsens. München: Otto Sagner.

Neweklowsky, G. 1978. Die kroatischen Dialekte des Burgenlandes. Wien: Österreichische Akademie der Wissenschaften.

Raguž, D. 1997. Praktična hrvatska gramatika. Zagreb: Medicinska naklada.

Rohlfs, G. 1969. Grammatica storica della lingua italiana e dei suoi dialetti. Sintassi e formazione delle parole. Torino: Einaudi.

Scholze, L. 2008. Das grammatische System der obersorbischen Umgangssprache im Sprachkontakt. Mit Grammatiktafeln im Anhang. Bautzen.

Stunová, A. 1986. "Aspect and Iteration in Russian and Czech. A Contrastive Study". In Dutch Studies in Russian Linguistics, edited by A. Barentsen, B. M. Groen, and R. Sprenger. Amsterdam: Rodopi, 467-501. 